\title{
Pathogenic bacteria isolated from disease outbreaks in shellfish hatcheries. First description of Vibrio neptunius as an oyster pathogen
}

\author{
Susana Prado ${ }^{1, *}$, Jesús L. Romalde1, Jaime Montes ${ }^{2}$, Juan L. Barja ${ }^{1}$ \\ ${ }^{1}$ Departamento de Microbiología y Parasitología, Facultad de Biología, Universidad de Santiago de Compostela, \\ 15782 Santiago de Compostela, Spain \\ ${ }^{2}$ Centro de Investigacións Mariñas, Xunta de Galicia, Aptdo. 13, 36620 Vilanova de Arousa, Spain
}

\begin{abstract}
Shellfish hatcheries are often affected by disease outbreaks. Three such episodes were investigated in different Galician hatcheries in order to establish the relationship between present microbiota and mortalities. Isolates were obtained from various parts of the hatcheries. Experimental tests for pathogenicity were carried out in microscale experiments using selected strains on Ostrea edulis larvae. The pathogenicity of 1 strain from each outbreak was demonstrated and shown to cause high mortalities (ranging from 98.5 to 100\%) in 72 to $96 \mathrm{~h}$ after inoculation of larval cultures. All 3 strains belong to the genus Vibrio. One of the strains was identified as Vibrio neptunius and is the first description of this species as a molluscan pathogen. The other 2 strains showed low similarity with the Vibrio species analysed and may constitute new species within this genus.
\end{abstract}

KEY WORDS: Flat oyster $\cdot$ Vibrio $\cdot$ Vibrio neptunius $\cdot$ Pathogenicity test $\cdot$ Shellfish hatchery

\section{INTRODUCTION}

The coast of Galicia (NW Spain) is an exceptional environment for shellfish aquaculture, which thus represents an economically relevant sector for the region. Among other molluscs, flat oyster Ostrea edulis and various clam species (Ruditapes decussatus, $R$. philippinarum, Venerupis pullastra) are widely cultured because of their high value and rapid growth in this area. The decline of natural beds has resulted in the need to establish hatcheries to provide farms with juveniles (Montes et al. 1992). Shellfish hatcheries in Galicia rear several species in the same facilities, usually combining flat oyster and different species of clams. However, they are not able to supply enough spat of these bivalves to all shellfish farmers. Juveniles are therefore imported from different countries, a practice that can facilitate entry of non-indigenous pathogens. Although culture techniques for efficient husbandry have been developed, hatcheries suffer epizootic episodes, often causing the complete loss of batches. As a result, the inability to ensure constant production makes the development of oyster and clam farming difficult.
Optimal conditions for growth and development of bivalve larvae in hatcheries (densities, temperature, load of organic matter, etc.) enhance the growth and multiplication of bacteria and the accumulation of their metabolites (Brown \& Tettelbach 1988, Araya et al. 1999). It is well known that bacteria are associated with decreased growth and mortalities in the larvae and juveniles of many bivalve molluscs. Walne (1958) reported the relationship between bacteria and growth problems of oyster larvae. In 1959, Guillard published a study about specific bacteria causing mortalities in Mercenaria mercenaria larvae. Tubiash et al. (1965) established the term 'bacillar necrosis' to name a characteristic disease caused by Vibrio spp. in different bivalve larvae. Further work on this subject confirmed the link between bacteria and disease in several mollusc species, including Ostrea edulis, Crassostrea virginica, C. gigas, M. mercenaria, Mytilus galloprovincialis and species of pectinids (Tubiash et al. 1970, Helm \& Smith 1971, Brown \& Losee 1978, DiSalvo et al. 1978, Elston \& Leibovitz 1980, Brown 1981, Elston et al. 1982, Jeffries 1982, Brown 1983, Bolinches et al. 1986, Tubiash \& Otto 1986, Lodeiros et al. 1987, Brown \& 
Tettelbach 1988, Lodeiros et al. 1992, Riquelme et al. 1995, Nicolas et al. 1996, Sáinz et al. 1998, Sugumar et al. 1998, Araya et al. 1999, Elston et al. 1999, Lacoste et al. 2001, Anguiano-Beltrán et al. 2004, Estes et al. 2004, Gay et al. 2004).

In this paper, we present the results of bacteriological studies performed during 3 episodes of severe mortalities in 3 shellfish hatcheries in Galicia. The pathogenicity of isolated bacterial strains was tested in order to identify the aetiological agents. In addition, the first evidence of Vibrio neptunius as mollusc pathogen is presented.

\section{MATERIALS AND METHODS}

Description of facilities and bacterial isolation. The facilities where mortalities occurred are situated at different locations along the Galician coast in NW Spain (Fig. 1). Their management practices vary: one is a commercial hatchery beside a molluscan depuration facility (hatchery A); the second is a plant where molluscs and fishes are cultured (hatchery B); and the third is exclusively dedicated to molluscs (hatchery C). Two of the facilities (B and C) suffered mortalities in oyster larval stages and one (A) in post-larvae.

Samples were taken in the different areas of the hatcheries: larvae, spat, broodstock, tank surfaces, phytoplankton and water. Larvae, spat and broodstock gonad (pieces excised aseptically) were washed, ground and homogenized in sterile seawater (SSW). Appropriate dilutions were made with these suspensions as well as with samples of water and phytoplankton used as larval feed. They were spread on Marine Agar (MA, Pronadisa) and Thiosulphate Citrate Bile Sucrose (TCBS, Oxoid). Samples taken directly from inner surfaces of the tanks containing the oysters were spread on the above mentioned media with sterile swabs.

Plates were incubated at $22^{\circ} \mathrm{C}$ and selected colonies were isolated after $24 \mathrm{~h}$ (TCBS) or $7 \mathrm{~d}$ (MA) on MA, and further restreaked to purity. Pure cultures of strains were frozen at $-80^{\circ} \mathrm{C}$ in Marine Broth with glycerol (15\% v/v).

Pathogenicity tests. Pathogenicity assays were carried out in 6-well sterile plastic cell-culture microplates (Nunc). Oyster larvae (10 to $15 \mathrm{~d}$ old) obtained from the 3 different hatcheries were placed in each well with $10 \mathrm{ml}$ of SSW at an average density of 11 larvae $\mathrm{ml}^{-1}$. Microplates were incubated on an orbital shaker (100 rpm) at room temperature $\left(22^{\circ} \mathrm{C}\right)$. No food was added during the experimental period.

Nineteen isolates obtained from the outbreaks were cultured on MA plates for $24 \mathrm{~h}$ at $22^{\circ} \mathrm{C}$. Suspensions of bacterial cultures of each isolate were prepared in SSW, adjusted by optical density of McFarland scale (tube 3). Bacteria were added to wells to achieve final concentrations of $10^{5}$ to $10^{6}$ colony forming units per

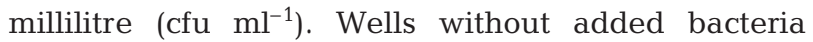
served as negative controls for all experiments. Bioassays were performed in duplicate.

Larvae were observed under light microscopy $(4 \times$ to $10 \times)$ and the effects of the bacteria recorded as follows:

(1) Live larvae, including swimming larvae and larvae with valves closed but showing internal movement;

(2) Dead larvae, or closed larvae without internal movement.

Pathogenicity results were expressed as mean percentages of mortality, and standard deviations were calculated (Sokal \& Rohlf 1995). Isolates showing mortalities lower than $10 \%$ were considered nonpathogenic.

Identification of pathogenic strains. Isolates showing pathogenic properties were examined for their phenotypic characteristics as described by Romalde et al. (1990). Cell morphology and motility were determined by phase-contrast microscopy. Routine oxidase, catalase and Gram tests were conducted. Growth in TCBS was observed. The oxidation-fermentation of glucose was performed in ZOF (ZoBell-based oxidationfermentation) (Lemos et al. 1985). Aminoacid decarboxylation was determined in Moeller's medium, and Thornley's arginine-dihydrolase test was also performed. Indol production, Voges-Proskauer, nitrate reduction and Simmon's citrate commercial media were prepared with the addition of $1.0 \% \mathrm{NaCl}$. The extracellular enzymes produced were examined for starch, gelatine, lipase (Tween 80) and esculine.

The $\mathrm{NaCl}$ requirement was determined by plating isolates on basal medium $\left(4.0 \mathrm{~g} \mathrm{l}^{-1}\right.$ peptone $+1.0 \mathrm{~g} \mathrm{l}^{-1}$ yeast extract $+15 \mathrm{~g} \mathrm{l}^{-1}$ agar) containing $0,0.5,3,6,8$ and $10 \% \mathrm{NaCl}$ and incubated for up to $1 \mathrm{wk}$. The tem-

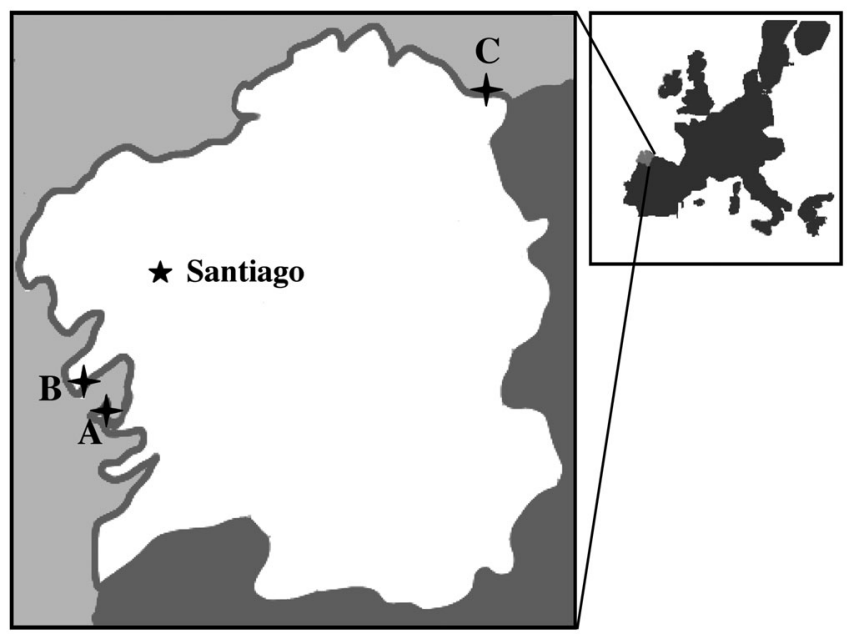

Fig. 1. Location of the hatcheries (A, B, and C) in NW Spain 
perature range of growth was determined by plating isolates on MA plates and incubating them at $6,15,25$, 35 and $43^{\circ} \mathrm{C}$ for up to $2 \mathrm{wk}$. Antibiograms were carried out by disc diffusion methodology, using antibioticimpregnated discs (Oxoid or BBL) with: amoxicillin $25 \mu \mathrm{g}$ (AML25), cephalexin $30 \mu \mathrm{g}$ (CL30), enrofloxacine $5 \mu \mathrm{g}$ (ENR5), erythromicine $15 \mu \mathrm{g}$ (E15), florfenicol $30 \mu \mathrm{g}$ (FFC30), flumequine $30 \mu \mathrm{g}$ (UB30), nalidixic acid $30 \mu \mathrm{g}$ (NA30), nitrofurantoin $300 \mu \mathrm{g}$ (F300), oxytetracycline $30 \mu \mathrm{g}$ (OT30), sulphamethoxazole/trimethoprim $25 \mu \mathrm{g}$ (SXT25) or tetracycline $30 \mu \mathrm{g}$ (TE30). The vibriostatic agent, pteridine (O/129 $150 \mu \mathrm{g})$, was also included. The inhibition zone was determined on MA after 24 to $48 \mathrm{~h}$ at $25^{\circ} \mathrm{C}$.

Additional phenotypic analyses were performed using the API20E system (bioMérieux) according to the manufacturer's instructions, except that saline solution $(\mathrm{NaCl} 0.85 \%$ ) was used to prepare the inocula.

Genetic characterization by sequencing of the $16 \mathrm{~S}$ rRNA gene was also carried out. Isolation of DNA from pure cultures was performed using the 'Instagene' matrix (Bio-Rad), following the manufacturer's recommendations. 16S rRNA genes were amplified by PCR with universal primers pA and $\mathrm{pH}$ (Hutson et al. 1993). Primers (Funke et al. 1995) corresponding to internal conserved regions of this gene were used for the sequencing reactions in a GeneAmp PCR System 9600 (Perkin Elmer), using a Taq dye-Deoxy terminator cycle sequencing kit (Applied Biosystems). Sequencing products were analysed using an Automatic DNA Sequencer (model 373A, Applied Biosystems). Comparative sequence analyses were conducted using FASTA3 program. Sequences of the closest relatives were retrieved from Gene bank/EMBL, and the alignments and phylogenetic analysis were performed by the neighbourjoining method using the ClustalW (Thompson et al. 1994). Bootstraps were calculated with 1000 replications, and Vibrio cholerae (X74695) was used as the outgroup sequence. The phylogenetic tree was drawn using the software NJPlot (Perrière \& Gouy 1996).

\section{RESULTS}

\section{Isolation of bacteria}

In the 3 hatcheries, samples were taken after the appearance of disease indicators, including growth depression, reduction of motility, abnormal swimming, velum deformation in the larval stages or the clearance of the spat mass in the bottom of the bins at postlarval stages.

In hatchery $\mathrm{A}$, with continuous mortalities of young spat $(<500 \mu \mathrm{m}$ in size $)$, bacteriological samples revealed that vibrios were the predominant bacteria, with approximately $10^{3} \mathrm{cfu}^{-1}$ pat $^{-1}$ on both TCBS and
MA media. A batch with early signs of disease showed a similar level of vibrios $\left(\approx 10^{3} \mathrm{cfu} \mathrm{spat}^{-1}\right)$, while lower numbers $\left(<10^{1} \mathrm{cfu}^{-1}\right.$ spat $\left.^{-1}\right)$ were observed in a healthy batch analysed in parallel. Analysis of seawater used in the hatchery showed the absence of growth in TCBS. Samples obtained directly from tank surfaces also showed a predominance of vibrios. A total of 5 isolates corresponding to the predominant bacterial phenotypes observed were selected from this hatchery (Table 1).

In hatcheries B and C larval cultures were affected. The first sign was growth depression and shortly before settlement larvae began to die. Mortalities were higher in small individuals $(\approx 150 \mu \mathrm{m})$ than in large ones $(>200 \mu \mathrm{m})$. In hatchery $\mathrm{B}, 2$ samples were collected, the first when the first signs of disease were observed and the second when mortalities appeared. A change in bacterial populations was recorded, with no vibrios detected in the first sample, and a dominant yellow colony recovered on TCBS in the second (Table 1). Oyster broodstock, kindly provided in this case by the farmer, allowed us to investigate the possibility of vertical transmission of the pathogenic bacteria. However, bacterial phenotypes observed in these samples did not correspond with those observed in diseased larvae (Table 1). A total of 9 isolates was recovered from diseased larvae and culture water in hatchery $\mathrm{C}$ (Table 1).

Table 1. Strains associated with disease outbreaks isolated in this study. TCBS = Thiosulphate Citrate Bile Sucrose; MA = Marine Agar

\begin{tabular}{|c|c|c|c|}
\hline Hatchery & Strain & Sample & $\begin{array}{l}\text { Medium } \\
\text { of isolation }\end{array}$ \\
\hline A & $\begin{array}{l}156 \\
157 \\
160 \\
182 \\
203\end{array}$ & $\begin{array}{l}\text { Diseased spat } \\
\text { Diseased spat } \\
\text { Diseased spat } \\
\text { Inner tank surface } \\
\text { Inner tank surface }\end{array}$ & $\begin{array}{c}\text { TCBS } \\
\text { TCBS } \\
\text { TCBS } \\
\text { TCBS } \\
\text { MA }\end{array}$ \\
\hline B & $\begin{array}{l}143.98 \\
145.98 \\
151.98 \\
318.98 \\
319.98\end{array}$ & $\begin{array}{l}\text { Diseased larvae } \\
\text { Diseased larvae } \\
\text { Diseased larvae } \\
\text { Broodstock } \\
\text { Broodstock }\end{array}$ & $\begin{array}{c}\text { MA } \\
\text { TCBS } \\
\text { MA } \\
\text { MA } \\
\text { MA }\end{array}$ \\
\hline $\mathrm{C}$ & $\begin{array}{l}632 \\
633 \\
634 \\
636 \\
637 \\
638 \\
650 \\
651 \\
652\end{array}$ & $\begin{array}{l}\text { Water }^{\mathrm{a}} \\
\text { Water }^{\mathrm{a}} \\
\text { Water }^{\mathrm{b}} \\
\text { Water }^{\mathrm{b}} \\
\text { Water }^{\mathrm{b}} \\
\text { Water }^{\mathrm{b}} \\
\text { Diseased larvae } \\
\text { Diseased larvae } \\
\text { Diseased larvae }\end{array}$ & $\begin{array}{l}\text { TCBS } \\
\text { TCBS } \\
\text { TCBS } \\
\text { TCBS } \\
\text { TCBS } \\
\text { TCBS } \\
\text { MA } \\
\text { MA } \\
\text { MA }\end{array}$ \\
\hline
\end{tabular}




\section{Pathogenicity tests}

Pathogenicity assays were conducted with the isolates obtained from the different hatcheries to determine their pathogenicity to flat oyster larvae. In each of 3 disease outbreaks, it was possible to demonstrate the association of one of the selected isolates with high mortalities in the experimental challenges (Table 2).

Strains PP-203 (hatchery A), PP-145.98 (hatchery B) and PP-638 (hatchery C) were able to cause high mortalities in 72 to $96 \mathrm{~h}(98.5,100$ and $100 \%$, respectively). The 'spotting' phenomenon, defined as an accumulation of larvae agglutinated in the bottom of the well, was evident after this period. Microscopical examination showed that, in all cases, the first sign of disease was reduction of motility, followed by an abnormal circular pattern of swimming or the inability to swim. In addition, we detected larvae with closed valves but internal movement and, to a lesser extent, with velum abnormalities or even detached portions of velum, which continued to move. Moreover, at the peak of the infections, bacteria swarming inside and around dead and moribund larvae were observed (Fig. 2). On the other hand, larval survival was higher than $94 \%$ for all the other isolates tested. Mortality in the negative controls ranged from 0 to $3.7 \%$.

Table 2. Mortality rates (\%) of oyster larvae obtained in experimental challenges using the bacterial strains isolated from mollusc culture systems. Inoculated doses ranged from $10^{5}$ to $10^{6} \mathrm{cfu} \mathrm{ml}^{-1} \cdot \mathrm{C}=$ negative control

\begin{tabular}{|c|c|c|c|c|c|}
\hline \multirow[t]{2}{*}{ Origin } & \multirow[t]{2}{*}{ Strain } & \multicolumn{4}{|c|}{ Time after inoculation (h) } \\
\hline & & 24 & 48 & 72 & 96 \\
\hline \multirow[t]{6}{*}{ Hatchery A } & $\mathrm{C}$ & 2.6 & 3.4 & 3.7 & - \\
\hline & 156 & 1.5 & 2.7 & 3.2 & - \\
\hline & 157 & 3.8 & 4.1 & 4.5 & - \\
\hline & 160 & 1.9 & 1.9 & 2.7 & - \\
\hline & 182 & 0.8 & 1.6 & 1.6 & - \\
\hline & 203 & 86.4 & 98.5 & 98.5 & - \\
\hline \multirow[t]{6}{*}{ Hatchery B } & $\mathrm{C}$ & 0.0 & 0.0 & - & 0.0 \\
\hline & 143.98 & 0.0 & 0.0 & - & 0.0 \\
\hline & 145.98 & 76.8 & 98.6 & - & 100.0 \\
\hline & 151.98 & 0.0 & 0.0 & - & 0.0 \\
\hline & 318.98 & 0.0 & 0.8 & - & 1.8 \\
\hline & 319.98 & 0.0 & 0.3 & - & 5.8 \\
\hline \multirow[t]{10}{*}{ Hatchery C } & $\mathrm{C}$ & - & 0.1 & - & 0.1 \\
\hline & 632 & - & 0.0 & - & 0.0 \\
\hline & 633 & - & 0.0 & - & 0.0 \\
\hline & 634 & - & 0.3 & - & 0.3 \\
\hline & 636 & - & 0.0 & - & 0.0 \\
\hline & 637 & - & 0.0 & - & 0.0 \\
\hline & 638 & - & 100.0 & - & 100.0 \\
\hline & 650 & - & 0.0 & - & 0.0 \\
\hline & 651 & - & 1.2 & - & 1.2 \\
\hline & 652 & - & 0.5 & - & 42.1 \\
\hline
\end{tabular}

\section{Identification of pathogenic strains}

The 3 pathogenic strains were Gram-negative, oxidase and catalase-positive, motile rods. They were fermentative in ZOF and OF medium, susceptible to vibriostatic agent and grew in TCBS. These characteristics indicate that they belong to the genus Vibrio.

All 3 strains were positive for acid production from glucose, amylase, gelatinase, lipase and for growth with 3 to $6 \% \mathrm{NaCl}$ and at 15 to $25^{\circ} \mathrm{C}$. They were negative for gas production from glucose, lysine- and ornitine-decarboxylases, Simmon's citrate (with and without $\mathrm{NaCl}$ addition), hydrolysis of esculine, $\mathrm{H}_{2} \mathrm{~S}$ production, urease and for growth without $\mathrm{NaCl}$ as well as at 4 to $6^{\circ} \mathrm{C}$ or $43^{\circ} \mathrm{C}$. Antibiotic susceptibility was observed to E15, FFC30, SXT25, UB30; and resistance to TE30, NA30 and OT30. All of them fermented glucose, but not inositol, sorbitol, rhamnose or arabinose.

Differential characteristics are illustrated in Table 3. Strain PP-145.98 was positive for arginine-dihydrolase and growth in $8 \% \mathrm{NaCl}$ and at $35^{\circ} \mathrm{C}$, and formed yellow colonies in TCBS agar. It was negative for indole production and nitrate reduction. Strain PP-203 was negative for arginine-dihydrolase, indole production, nitrate reduction, growth in $8 \% \mathrm{NaCl}$ and at $35^{\circ} \mathrm{C}$, and formed green colonies in TCBS. Strain PP-638 was positive for arginine-dihydrolase, indole production, nitrate reduction, growth in $0.5 \% \mathrm{NaCl}$ and formation of yellow colonies in TCBS. It was negative for growth in $8 \% \mathrm{NaCl}$ and at $35^{\circ} \mathrm{C}$.

The 16S rDNA sequences of the pathogenic isolates were determined and were allocated to the genus Vibrio using the FASTA program. Clustering obtained by the Clustal method indicated that PP-145.98 belongs to

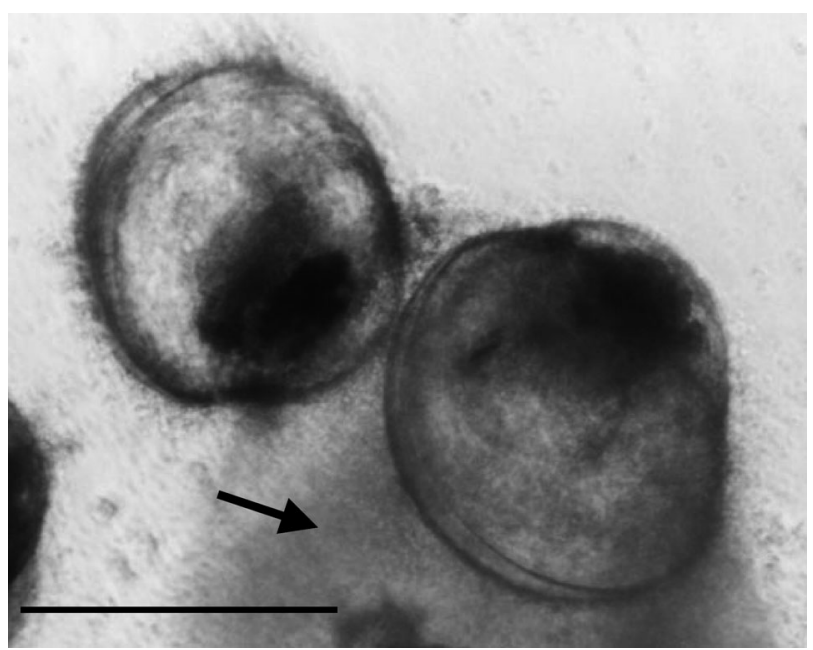

Fig. 2. Disease signs of oyster larvae in the experimental challenges: bacterial swarming around spotted larvae. Arrow indicates accumulation of bacterial cells. Scale bar $=200 \mu \mathrm{m}$ 
Table 3. Differential phenotypic characteristics of the pathogenic strains. $\mathrm{R}=$ resistant; $\mathrm{S}=$ susceptible

\begin{tabular}{|lccc|}
\hline Test & PP-145.98 & PP-203 & PP-638 \\
\hline Growth on TCBS & + (yellow) & + (green) & + (yellow) \\
Arginine-dihydrolase & + & - & + \\
Nitrate reduction & - & - & + \\
Indole production & - & - & + \\
Voges-Proskauer & - & - & + \\
ONPG ( $\beta$-galactosidase) & - & - & + \\
Fermentation of: & & & \\
manose & - & - & + \\
sucrose & + & - & + \\
melibiose & - & - & + \\
amigdaline & - & - & + \\
Growth at: & & & \\
35 C & + & - & - \\
0.5\% NaCl & - & - & + \\
$8 \%$ NaCl & $(+)$ & - & - \\
Amoxicillin & $\mathrm{R}$ & $\mathrm{R}$ & $\mathrm{S}$ \\
Cephalexin & $\mathrm{S}$ & $\mathrm{R}$ & $\mathrm{S}$ \\
Enrofloxacine & $\mathrm{R}$ & $\mathrm{S}$ & $\mathrm{R}$ \\
Nitrofurantoin & $\mathrm{S}$ & $\mathrm{R}$ & $\mathrm{S}$ \\
\hline
\end{tabular}

Vibrio neptunius, with a similarity of $99.47 \%$. Strains PP203 and PP-638 showed low values of similarity ( $\leq 97 \%$ ) with the other Vibrio species included in the analysis. In the case of PP-203, the closest phylogenetic relatives were $V$. vulnificus (97.38\%), V. aestuarianus (97.22\%), $V$. splendidus biovar II (97.15\%), V. parahaemolyticus $(97.07 \%)$ and $V$. chagassi $(97.07 \%)$, while PP-638 was more similar to $V$. orientalis $(96.93 \%), V$. campbellii (96.66\%), V. mytili (96.54\%) and V. tubiashii (96.51\%). Fig. 3 shows the phylogenetic tree obtained after the neighbour-joining analysis.

16S rDNA sequences of PP-145.98, PP-203 and PP638 were deposited in the EMBL database with accession numbers AJ296157, AJ296159 and AY792622, respectively.

\section{DISCUSSION}

A large number of works, as detailed in the introduction, have established bacterial implication in outbreaks of disease in molluscan larval cultures. Usual culture conditions, such as high larval density, high temperatures and addition of food, favour the appearance of high concentrations of bacteria in the hatcheries (Walne 1958), many of them with pathogenic potential. Proliferation of opportunistic pathogens may lead to outbreaks of disease. The identification of pathogens affecting cultures in a determined area is the first step towards establishing measures for disease control. For this purpose, different approaches, such as UV-treatment of water or use of chemotherapeutants, are commonly employed. However, these treatments can favour the proliferation of specific bacterial populations able to survive in adverse conditions or resistant to antibiotics (Davies 1994), which may constitute a risk for larvae.

In this study we investigated 3 episodes of mortality that occurred in Galician hatcheries. In all cases, an

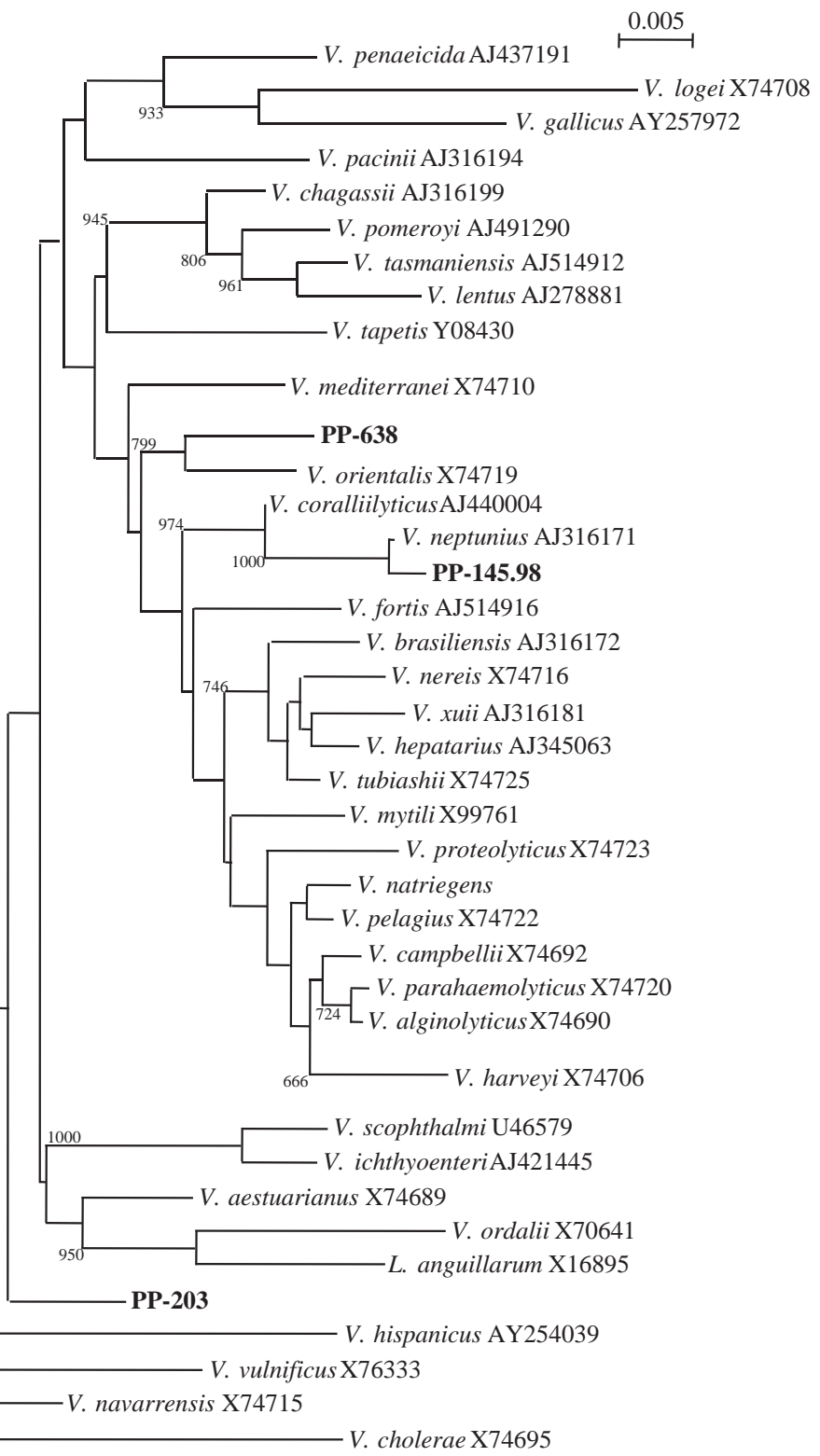

Fig. 3. Phylogenetic tree of $16 \mathrm{~S}$ rRNA sequences for the pathogenic strains obtained in this study and the type strains of the closest relatives within the genus Vibrio. V. cholerae (Acc. No. X74695) was employed as outgroup. Horizontal branch lengths are proportional to evolutionary divergence. Significant bootstrap values of 1000 replicates appear next to the corresponding branch 
increase in the numbers of bacteria in water, mainly representatives of the genus Vibrio, were observed in comparison with bacterial levels in healthy larval cultures. This fact confirms the quick proliferation of opportunistic pathogens naturally present in the culture system when conditions are favourable (DiSalvo 1978, Jeffries 1982). Initially, before invasion of larvae, bacteria may be present in water, but after colonization they multiply rapidly, usually attached to larvae, and are more difficult to detect in water (Brown 1981, Brown \& Tettelbach 1988). This could explain why none of the isolates from water of cultures showing high mortalities was able to cause larval death. On the other hand, mortalities were higher in smaller larvae from the same batch. This greater susceptibility to infection seems logical, taking into account that smaller individuals always show slower development, a slight protective shell, and are usually unable to settle (Elston 1984).

We have been able to demonstrate the ability of at least one isolate from each outbreak to cause severe mortalities in larval cultures. In the experimental challenges, pathogenic isolates caused high mortalities (98 to $100 \%$ ) in less than $48 \mathrm{~h}$. This fact is of particular importance because water in tanks at hatcheries is renewed every 2 to $3 \mathrm{~d}$ and the whole batch could die within this period. Signs observed in the laboratory trials, including reduction of motility and spotting phenomenon, have been related to the action of bacterial toxins (DiSalvo et al. 1978). These findings, together with the fact that bacterial swarming was observed around larvae, indicate that the pathogenic action could correspond to vibriosis type I (Elston \& Leibovitz 1980). This hypothesis was confirmed, since all aetiological agents were identified as belonging to the genus Vibrio. Characterization of the strain PP-145.98 indicates that it belongs to Vibrio neptunius (Thompson et al. 2003). Although it has been reported as normal microbiota in cultures of rotifers and larvae of bivalves and fish (Suantika et al. 2001, Thompson et al. 2003), our results constitute the first evidence of pathogenicity for molluscs of this Vibrio species. Strains PP203 and PP-638, although belonging to the same genus, could not be assigned to any known species.

In hatchery A, the pathogenic strain PP-203 was isolated from surfaces of nursery culture containers. It may be possible that this strain is able to survive the water changes, forming biofilms on the inner tank surfaces (Elston 1984). Protection of bacteria from adverse environmental conditions, including desiccation, has been described as one of the ecological advantages of biofilms (Ophir \& Gutnick 1994, Davey \& O'Toole 2000). Moreover, it has to be taken into account that the same tanks are used to culture different species (oyster and clams), and preliminary results indicate the pathogenicity of this strain to clam larvae (data not shown). All these facts emphasize that proper cleaning of tanks is critical for control of pathogen persistence in the culture systems (Elston 1984).

In hatcheries $\mathrm{B}$ and $\mathrm{C}$ growth depression was detected in larval cultures, which caused delays in settlement, followed by death. During settlement and metamorphosis, the most critical stages in larval development, larvae begin a life associated with substrate in high densities and come into contact with the resident microbiota and, hence, with putative pathogens (Sutton \& Garrick 1993). All these factors can facilitate the transmission or appearance of diseases.

In summary, the relationship between new bacteria belonging to the genus Vibrio and collapses of larval and post-larval cultures of bivalves was established, showing that these opportunistic pathogens are responsible for important losses in Galician hatcheries. Moreover, the pathogenic capacities for molluscs of Vibrio neptunius were demonstrated. Further studies are needed with the other pathogenic strains detected in order to characterize them fully and, thus, possibly to describe new Vibrio species.

Acknowledgements. This work was supported in part by Grant PGIDT02RMAAE1 from the Consellería de Pesca e Asuntos Marítimos, Xunta de Galicia (Spain). We thank Dr. C. R. Osorio for his valuable help in the sequencing of the strains. The authors are also grateful to the farmers for facilitating the samplings.

\section{LITERATURE CITED}

Anguiano-Beltrán C, Lizárraga-Partida ML, Searcy-Bernal R (2004) Effect of Vibrio alginolyticus on larval survival of the blue mussel Mytilus galloprovincialis. Dis Aquat Org 59:119-123

Araya RA, Jorquera MA, Riquelme CE (1999) Asociación de bacterias al ciclo de vida de Argopecten purpuratus. Rev Chil Hist Nat 72:261-271

Bolinches J, Toranzo AE, Silva A, Barja JL (1986) Vibriosis as the main causative factor of heavy mortalities in the oyster culture industry in North-western Spain. Bull Eur Assoc Fish Pathol 6:1-4

Brown C (1981) A study of two shellfish-pathogenic Vibrio strains isolated from a Long Island hatchery during a recent outbreak of disease. J Shellfish Res 1:83-87

Brown C (1983) Bacterial diseases in bivalve larval cultures and their control. In: Berg CJ Jr (ed) Culture of marine invertebrates, Selected Readings. Hutchinson Ross Publishing Company, Stroudsburg, PA, p 230-242

Brown C, Losee E (1978) Observations on natural and induced epizootics of vibriosis in Crassostrea virginica larvae. J Invertebr Pathol 31:41-47

Brown C, Tettelbach LP (1988) Characterization of a nonmotile Vibrio sp. pathogenic to larvae of Mercenaria mercenaria and Crassostrea virginica. Aquaculture 74:195-204

Davey ME, O'Toole GA (2000) Microbial biofilms: from ecology to molecular genetics. Microbiol Mol Biol Rev 64: $847-867$ 
Davies J (1994) Inactivation of antibiotics and the dissemination of resistance genes. Science 264:375-382

DiSalvo LH, Blecka J, Zebal R (1978) Vibrio anguillarum and larval mortality in a California coastal shellfish hatchery. Appl Environ Microbiol 35:219-22

Elston R (1984) Prevention and management of infectious diseases in intensive mollusc husbandry. J World Maricult Soc 15:284-300

Elston R, Leibovitz L (1980) Pathogenesis of experimental vibriosis in larval American oysters, Crassostrea virginica. Can J Fish Aquat Sci 37:964-978

Elston R, Elliot EL, Colwell RR (1982) Conchiolin infection and surface coating Vibrio: shell fragility, growth depression and mortalities in cultured oysters and clams, Crassostrea virginica, Ostrea edulis and Mercenaria mercenaria. J Fish Dis 5:265-284

Elston RA, Frelier P, Cheney D (1999) Extrapallial abscesses associated with chronic bacterial infections in the intensively cultured juvenile Pacific oyster Crassostrea gigas. Dis Aquat Org 37:115-120

Estes RM, Friedman CS, Elston RA, Herwig RP (2004) Pathogenicity testing of shellfish hatchery bacterial isolates on Pacific oyster Crassostrea gigas larvae. Dis Aquat Org 58: 223-230

Funke G, Ramos CP, Collins MD (1995) Identification of some clinical strains of CDC coryneform group A-3 and A-4 bacteria as Cellulomonas species and proposal of Cellulomonas hominis sp.nov. for some group A-3 strains. J Clin Microbiol 33:2091-2097

Gay M, Berthe FCJ, Le Roux F (2004) Screening of vibrio isolates to develop an experimental infection model in the Pacific oyster Crassostrea gigas. Dis Aquat Org 59:49-56

Guillard RRL (1959) Further evidence of the destruction of bivalve larvae by bacteria. Biol Bull 117:258-266

Helm MM, Smith FM (1971) Observation of bacterial diseases in laboratory culture larvae of the European flat-oyster, Ostrea edulis L. Int Counc Explor Sea, ICES-CM 1971/K 10

Hutson RA, Thompson DE, Collins MD (1993) Genetic interrelationships of saccharolytic Clostridium botulinum types $\mathrm{B}, \mathrm{E}$ and $\mathrm{F}$ and related clostridia as revealed by small-subunit rRNA gene sequences. FEMS Microbiol Lett 108: 103-110

Jeffries VE (1982) Three Vibrio strains pathogenic to larvae of Crassostrea gigas and Ostrea edulis. Aquaculture 29: 201-226

Lacoste A, Jalabert F, Malham SK, Cueff A, Poulet SA (2001) Stress and stress-induced neuroendocrine changes increase the susceptibility of juvenile oyster (Crassostrea gigas) to Vibrio splendidus. Appl Environ Microbiol 67:2304-2309

Lemos ML, Toranzo AE, Barja JL (1985). Modified medium for the oxidation-fermentation test in the identification of marine bacteria. Appl Environ Microbiol 49:1541-1543

Lodeiros C, Bolinches J, Dopazo CP, Toranzo AE (1987) Bacillary necrosis in hatcheries of Ostrea edulis in Spain. Aquaculture 65:15-29

Lodeiros C, Freites L, Vélez A (1992) Necrosis bacilar en larvas del bivalvo Euvola ziczac (Linneo,1758) causada por una Pseudomonas sp., Acta Científica Venezolana 43: $154-158$

Editorial responsibility: Albert Sparks, Seattle, Washington, USA
Montes J, Carballal MJ, López MC, Mourelle S (1992) Incidence of bonamiasis in flat oyster, Ostrea edulis, cultured in Galicia. Aquaculture 107:189-192

Nicolas JL, Corre S, Gauthier G, Robert R, Ansquer D (1996) Bacterial problems associated with scallop Pecten maximus larval culture. Dis Aquat Org 27:67-76

Ophir T, Gutnick DL (1994) A role for expolysaccharide in the protection of microorganisms from desiccation. Appl Environ Microbiol 60:740-745

Perrière G, Gouy M (1996) WWW-query: an on-line retrieval system for biological sequence banks. Biochimie 78: 364-369

Riquelme C, Hayashida G, Vergara N, Vásquez A, Morales Y, Chávez, P (1995) Bacteriology of the scallop Argopecten purpuratus (Lamarck,1819) cultured in Chile. Aquaculture138:49-60

Romalde JL, Toranzo AE, Barja JL (1990) Changes in bacterial populations during red tides caused by Mesodinium rubrum and Gymnodinium catenatum in North West Coast of Spain. J Appl Bacteriol 68:123-132

Sáinz JC, Maeda-Martínez AN, Ascencio F (1998) Experimental vibriosis induction with Vibrio alginolyticus of larvae of the Catarina scallop (Argopecten ventricosus $=$ circularis) (Sowerby II, 1842). Microb Ecol 35:188-192

Sokal RR, Rohlf FJ (1995) Biometry: the principles and practice of statistics in biological research, 3rd edn. WH Freeman \& Co, New York

Suantika G, Dhert P, Rombaut G, Vandenberghe J, De Wolf T, Sorgeloos P (2001) The use of ozone in a high density recirculation system for rotifers. Aquaculture 201:35-49

Sugumar G, Nakai T, Hirata Y, Matsubara D, Muroga K (1998) Vibrio splendidus biovar II as the causative agent of bacillary necrosis of Japanese oyster Crassostrea gigas larvae. Dis Aquat Org 33:111-118

Sutton DC, Garrick R (1993) Bacterial disease of cultured giant clam Tridacna gigas larvae. Dis Aquat Org 16: $47-53$

Thompson FL, Li Y, Gómez-Gil B, Thompson CC and 7 others (2003) Vibrio neptunius sp.nov., Vibrio brasiliensis sp.nov. and Vibrio xuii sp.nov., isolated from the marine aquaculture environment (bivalves, fish, rotifers and shrimps). Int J Syst Evol Microb 53:245-252

Thompson JD, Higgins DG, Gibson TJ (1994) ClustalW: improving through sequence weighting, position specific gap penalties and weight matrix choice. Nucleic Acids Res 22:4673-4680

Tubiash HS, Otto SV (1986) Bacterial problems in oysters. A review. In: Vivarès $\mathrm{CP}$, Bonami JR, Jasper E (eds) Pathology in marine aquaculture, European Aquaculture Spec Publ 9, p 233-242

Tubiash HS, Chanley PE, Leifson E (1965) Bacillary necrosis,a disease of larval and juvenile bivalve mollusks. I. Etiology and epizootiology. J Bacteriol 90:1036-1044

Tubiash HS, Colwell RR, Sayazaki R (1970) Marine vibrios associated with bacillary necrosis, a disease of larval and juvenile bivalve mollusks. J Bacteriol 103:271-272

Walne PR (1958) The importance of bacteria in laboratory experiments on rearing the larvae of Ostrea edulis (L.). J Mar Biol Assoc UK 37:415-425

Submitted: December 2, 2004; Accepted: April 14, 2005

Proofs received from author(s): August 31, 2005 